\title{
Hepatoprotective Effect of Tribulus terrestris $L$ against Acetaminophen-Induced Liver Damage in Wistar Rats
}

\author{
Javed Akhtar Ansari, Abdul Mateen Sayyed, R Manavalan, Balamurgan
}

\begin{abstract}
Background: Nowaday's liver diseases due to exposure of different drug molecules are very common. The aim of the present study was to investigate the effect of methanolic extract of Tribulus terrestris $L(T T)$ against acetaminophen (AA)-induced liver damage in $\mathrm{W}$ istar rats.
\end{abstract}

Materials and methods: Animals were divided into five groups of six rats each.

Results and discussion: O ral administration of TT ( $500 \mathrm{mg} / \mathrm{kg}$ ) along with AA $(2.5 \mathrm{gm} / \mathrm{kg})$ showed a significant decrease in serum enzyme aspartate aminotransferase (AST), alanine aminotransferase (ALT), total bilirubin, direct bilirubin and alkaline phosphatase (ALP) levels with a decrease in total protein levels $(p<0.01)$. The results were comparable with silymarin $(S L)$, a standard hepatoprotective drug. The present study reveals that the administration of TT can be beneficial for the suppression of liver damage. Based on present findings, it can be concluded that methanolic extract of TT protects the liver from AA-induced liver damage. The present study for the first time reports the hepatoprotective potential of TT in AA-induced liver damage in $\mathrm{W}$ istar rats.

Keywords: Paracetamol, Hepatotoxicity, Liver enzymes.

How to cite this article: Ansari J A, Sayyed AM, Manavalan R, Balamurgan. Hepatoprotective Effect of Tribulus terrestris $L$ against Acetaminophen-Induced Liver Damage in W istar Rats. Euroasian J Hepato-G astroenterol 2013;3(1):15-18.

\section{Source of support: $\mathrm{Nil}$}

Conflict of interest: None

\section{INTRODUCTION}

Nowadays liver diseases due to exposure of different drug molecules are very common. ${ }^{1} \mathrm{~A} n$ attention must be paid to cure these hepatic disorders. The mainstay of treatment is supportive care, with careful monitoring for signs of acute liver failure or progression to chronic liver disease. ${ }^{2}$

The use of plants, plant extracts or plant-derived pure chemicals to treat disease is a therapeutic modality, which has stood the test of time. ${ }^{3}$ D espite phenomenal growth of modern medicine; there are almost no drugs available for the treatment of drug-induced hepatic diseases. However, there are numerous herbs/herbal formulations claimed have to possess valuable activity in treating hepatic disorders. Several hundred plants have been examined for use in a wide variety of liver disorders. J ust a handful has been fairly well evaluated. The latter category of plants includes: Silybum marianum (milk thistle), Picrorhiza kurroa (kutki),
Curcuma longa (turmeric), Camellia sinensis (green tea), Chelidonium majus (greater celandine), G lycyrrhiza glabra (licorice), and Allium sativa (garlic). ${ }^{4}$

Tribulus ter restris L (TT; Zygophyllaceae) is an annual plant native of M editerranean region, but now extensively distributed in the warm regions all over the world. ${ }^{5}$ It is employed in the folk medicine of India, China, Bulgaria and South A frica against sexual impotence, edemas, abdominal distention and cardiovascular diseases. ${ }^{5,6}$

There is no scientific basis or reports in the modern literature regarding its useful ness as hepatoprotective agent against acetaminophen (A A)-induced liver damage in W istar rat. Therefore, the present study was conducted to evaluate the effect of the methanolic extract of the TT fruits against A A-induced liver damage in $\mathrm{W}$ istar rats.

\section{MATERIALS AND METHODS}

\section{Chemicals}

$A A$, silymarin ( $S L$ ) (M icro Labs $L t d$, B engaluru, India), ethanol (SD Fine Chemicals L td, M umbai, India). A A was suspended in $0.5 \%$ gum acacia before use. All other chemicals and reagents were of the highest analytical grades available.

\section{Plant}

The fruits of TT were procured from Chidambaram, Cuddalore, Tamil Nadu, India, during the month of November. The plant was identified and authenticated by Prof. DrR Selvaraj, Chief B otanist, Department of B otany, A nnamalai University, A nnamalai Nagar, Chidambaram, Cuddalore, Tamil N adu, India. A voucher specimen has been kept at the herbarium of the U niversity.

\section{Preparation of Extract}

The fruits of TT were dried in shade, powdered and passed through a 40-mesh sieve. D ried pow der ( $500 \mathrm{gm}$ ) was taken and subjected to successive extraction with petroleum ether, chloroform, methanol and water in Soxhlet apparatus. The extracts were concentrated to dry residue by distillation (temperature $60^{\circ} \mathrm{C}$ without vacuum) and dried completely in desiccators and weighed. The yield of the methanol extract was $19.5 \% \mathrm{w} / \mathrm{w}$. The extract was freeze dried and 
stored at $-80^{\circ} \mathrm{C}$ until further use. The dried mass (yield $=$ $50.2 \mathrm{gm}$ ) was diluted with normal saline and used in experiments. The methanol extract was found to be effective as hepatoprotective.

\section{Preliminary Phytochemical Screening}

Petroleum ether, chloroform, methanol and aqueous extracts of TT were subjected to preliminary phytochemical screening for their presence or absence of active constituents utilizing standard method of analyses. ${ }^{7}$

\section{Animal}

The study was conducted after obtaining institutional ethical committee clearance bearing the number 160/1999/ CPCSEA (Committee for Control and Supervision on Experiments on A nimals). M ale W istar rats (100-150 gm; 4- 6 weeks old) were maintained under controlled conditions of light $(12 \mathrm{~h} / 12 \mathrm{~h})$, temperature $\left(26 \pm 2^{\circ} \mathrm{C}\right)$ and relative humidity (44-56\%) for 1 week before and during the experiments. The animals had access to standard laboratory feed (Gold M ohur, Hindustan Lever Ltd, M umbai, India) and water ad libitum. For experimental purposes, animals were kept fasting overnight but were allowed free access to water.

\section{Experimental Procedure}

A A was suspended in $0.5 \%$ gum acacia and administered orally at a single dose of $2.5 \mathrm{gm} / \mathrm{kg}$. This dose is known to induce liver damage in rats. ${ }^{8}$ A nimals were divided into five groups of six animals each. Group I (normal control, $\mathrm{NC}$ ) received saline $(0.9 \% \mathrm{NaCl}$, oral) $1 \mathrm{ml} / \mathrm{kg}$ and group $\mathrm{V}$ (TT per se) received TT $500 \mathrm{mg} / \mathrm{kg}$, orally, for 6 days. The group II (AA control), group III (TT + AA), group IV $(S L+A A)$ received $0.5 \%$ gum acacia in distilled water (1 ml/kg, po), methanolic extract of TT (500 mg/kg, orally and $\mathrm{SL}(100 \mathrm{mg} / \mathrm{kg}$, orally) respectively, once a day for 6 days. $0 n$ the fourth day, 30 minutes after the administration of the respective treatments, all the animals of groups II, III and IV were administered with A A ( $2.5 \mathrm{gm} / \mathrm{kg}$, orally). O n the sixth day after 2 hours of respective treatments, under ether anesthesia, blood samples were collected in centrifuge tubes via retro-orbital route, and the serum was separated.

\section{Biochemical Analysis}

The serum was separated after centrifuging the blood sample at 3,000 rpm for 15 minutes and the following enzyme analysis were quantified: A spartate aminotransferase (AST), al anine aminotransferase (ALT), ${ }^{9}$ total bilirubin, ${ }^{10}$ al kaline phosphatase (ALP) ${ }^{11}$ and total protein. ${ }^{12}$

\section{STATISTICAL ANALYSIS}

The obtained raw data in each experimental group was computed into mean and standard error of mean (SEM). Groups of data were compared with the analysis of variance (ANOVA) followed by Dunnett's test for multiple comparison of the two treatment groups with the control. $V$ alues were considered statistically significant when $p<0.01$.

\section{RESULTS}

\section{Preliminary Phytochemical Screening}

Alkaloids, carbohydrates, cardiac glycosides, flavonoids, saponins, tannins and proteins were found to be present in methanolic and aqueous extract while steroids were absent in all extracts. Chloroform extracts al so showed the presence of alkaloids.

\section{Biochemical Observations}

\section{Effect of AA on Serum Biochemical Parameters}

As shown in Table 1, administration of AA $(2.5 \mathrm{gm} / \mathrm{kg}$, orally) induced a marked increase in the serum enzyme A ST, $A L T$, total bilirubin, direct bilirubin and ALP levels as compared to the NC group ( $p<0.01)$. Total protein levels were significantly reduced in the AA control group as compared to the NC group $(p<0.01)$.

\section{Effect of TT on Serum Biochemical Parameters}

TT + AA group showed decrease in serum enzyme AST, $A L T$, total bilirubin, direct bilirubin and ALP levels as compared to the AA control group $(p<0.01)$. TT + AA group significantly increased the total protein levels as compared to the AA control group $(p<0.01)$ (Table 1$)$.

\section{Effect of SL on Serum Biochemical Parameters}

$\mathrm{SL}+\mathrm{AA}$ group showed decrease in serum enzyme AST, $A L T$, total bilirubin, direct bilirubin and ALP levels as compared to the AA control group $(p<0.01)$. SL + AA group significantly increased the total protein levels as compared to the AA control group $(p<0.01)$ (Table 1 ).

\section{Effect of TT per se on Serum Biochemical Parameters}

TT per se group showed nonsignificant changes in serum enzyme A ST, A LT, total bilirubin, direct bilirubin and ALP level s as compared to AA control group ( $p>0.05)$. TT per se group did not show a significant change in total protein levels as compared to NC group ( $p>0.05)$ (Table 1$)$. 
Hepatoprotective Effect of Tribulus terrestris L against Acetaminophen-Induced Liver Damage in Wistar Rats

Table 1: Effect of Tribulus terrestris $L$ administration on biochemical parameters in rats exposed to acetaminophen

\begin{tabular}{|c|c|c|c|c|c|}
\hline Parameters & NC & $A A$ & $\mathrm{TT}+\mathrm{AA}$ & $S L+A A$ & TT per se \\
\hline AST (U/L) & $54.30 \pm 0.315$ & $140.02 \pm 0.278^{\# \#}$ & $65.43 \pm 0.304^{* *}$ & $59.60 \pm 0.352^{* *}$ & $52.14 \pm 0.571^{* *}$ \\
\hline $\operatorname{ALT}(U / L)$ & $25.21 \pm 0.496$ & $62.11 \pm 0.287^{\# \#}$ & $27.36 \pm 0.450 * *$ & $20.81 \pm 0.344^{* *}$ & $23.45 \pm 0.401^{* *}$ \\
\hline ALP (U/L) & $96.10 \pm 0.194$ & $392.13 \pm 0.211^{\# \#}$ & $241.26 \pm 1.353^{* *}$ & $228.45 \pm 0.697^{* *}$ & $95.20 \pm 0.073^{* *}$ \\
\hline Total bilirubin (mg/100 ml) & $0.88 \pm 0.008$ & $2.16 \pm 0.025$ & $0.95 \pm 0.010^{* *}$ & $0.90 \pm 0.008^{* *}$ & $0.87 \pm 0.011^{* *}$ \\
\hline Direct bilirubin (mg/100 ml) & $0.25 \pm 0.004$ & $0.69 \pm 0.023^{\# \#}$ & $0.28 \pm 0.001^{* *}$ & $0.26 \pm 0.003^{* *}$ & $0.25 \pm 0.005^{* *}$ \\
\hline Total protein (gm /100 ml) & $5.14 \pm 0.035$ & $3.01 \pm 0.023^{\# \#}$ & $5.02 \pm 0.026^{* *}$ & $5.10 \pm 0.045^{* *}$ & $5.13 \pm 0.068^{* *}$ \\
\hline
\end{tabular}

$\mathrm{NC}$ : Normal control $(0.9 \% \mathrm{NaCl}, 1 \mathrm{ml} / \mathrm{kg}, \mathrm{po}) ; \mathrm{AA}$ : Acetaminophen control (2.5 gm/kg, po); TT: Tribulus terrestris L $(500 \mathrm{mg} / \mathrm{kg}, \mathrm{po}) ; \mathrm{TT}+\mathrm{AA}$ : Tribulus terrestris L. (500 mg/kg, po) + acetaminophen $(2.5 \mathrm{gm} / \mathrm{kg}, \mathrm{po}) ; \mathrm{SL}+\mathrm{AA}: \mathrm{SL}(100 \mathrm{mg} / \mathrm{kg}, \mathrm{po})+$ acetaminophen $(2.5 \mathrm{gm} / \mathrm{kg}, \mathrm{po})$; Values are mean \pm SEM of six animals in each group; ${ }^{\#} p<0.01$, as compared to NC group; ANOVA followed by Dunnett test; ${ }^{* *} p<0.01$, as compared to AA control group, ANOVA followed by Dunnett test

\section{DISCUSSION}

The present study focused on the hepatoprotective effect of TT on A A-induced liver damage in W istar rats and found that administration of TT suppressed significantly the increases in serum enzyme AST, A LT, total bilirubin, direct bilirubin and $A L P$, and stimulated the decreases in total protein levels $(p<0.01)$.

$A A$, also known as paracetamol, is extensively used as an analgesic and antipyretic drug, though proved safe at therapeutic doses; AA is toxic at higher doses and causes acute liver failure characterized by centrilobular hepatic necrosis. AA can also induce renal failure and ultimately death in severe cases. ${ }^{13}$

Serum A ST, A LT and bilirubin are the most susceptible biomarkers employed in the diagnosis of liver diseases. ${ }^{14}$ Throughout hepatocellular damage, varieties of enzymes normally located on the cytosol are released into the blood flow. Their quantification in serum is a valuable biomarker of the extent and type of hepatocellular damage. ${ }^{14} \mathrm{As}$ expected, a single oral dose of A A $(2.5 \mathrm{gm} / \mathrm{kg}, \mathrm{po})$ showed significant hepatotoxicity, as evidenced by a dramatic elevation of AST, ALT, ALP, bilirubin and suppression of total protein. Pretreatment along 2 days with TT showed a significant protective effect against A A-induced acute hepatotoxicity in rats. Serum aminotransferase activities have long been considered as sensitive markers of hepatic injury. ${ }^{15}$ Injury to the hepatocytes changes their transport function and membrane permeability, causes leakage of enzymes from the cells. Consequently, the significant release of $A L T$ and $A L P$ into the circulation indicates severe damage to hepatic tissue membranes during AA intoxication. The amplified activities of AST, A L T and A LP in the present study may be interpreted as a result of the liver cell destruction or alters in the membrane permeability representing the severity of hepatocellular damage induced by $A$ A, which is in accordance with previous report. ${ }^{16}$ The increase in $A L T$ activity is almost always due to hepatocellular injury and is usually accompanied by an increase in AST. An elevation in ALP reflects the pathological alteration in biliary flow. ${ }^{17}$

\section{CONCLUSION}

The results of the present investigation confirmed that A A caused changes in the levels of several liver components. The TT as well as SL when given orally was able to target the liver enzymes, and found to improve liver enzyme contents in A A-induced Wistar rats. These results present initial evidence that TT may be useful for the treatment of liver damage and raise the possibility of a new application as a hepatoprotective therapeutic modality.

\section{REFERENCES}

1. Ansari JA. Therapeutic approaches in management of druginduced hepatotoxicity. J Biol Sci 2010;10:386-95.

2. A nsari, JA, K han M, M irza AB. Liver toxicity caused by synthetic drugs. J Chem Pharmaceut Sci 2009;2:265-69.

3. A nsari JA, I namdar N N. The promise of traditional medicines. Int J Pharmacol 2010;6:808-12.

4. Luper NDS. A review of plants used in the treatment of liver disease, part 1. Alter M ed Rev 1998;3:410-21.

5. Jamil M, Ansari JA, Ali A, A hamad J, Ali M, Tamboli E. Pharmacological scientific evidence for the promise of Tribulus terrestris. Int Res J Pharm 2012;3:403-06.

6. Kostova I, Dinchev D, Rentsch GH, Dimitrov V, Ivanova A. T wo new sulfated furostanol saponins from Tribulus terrestris. Z N aturforsch C 2002;57:33-38.

7. Trease GE, Evans WC. A textbook of pharmacognosy (15th ed). L ondon: Saunders Publishers 2002.

8. M itra SK, V enkataranganna M V , Sundaram K, G opumadhavan S. Protective effect of HD-03, a herbal formulation against various hepatotoxic agents in rats. J Ethnopharmacol 1998;63:181-86.

9. Reitman S, Frankel AS. A colorimetric method for the determination of serum glutamic oxaloacetic and glutamic pyruvic transaminase. A mer J Clin Pathol 1957;28:56-63.

10. Malloy $H T$, Evelyn $K$. The determination of bilirubin with the photoelectric colorimeter. J Biol Chem 1937;119:481-85. 
11. Kind PRN, King EJ. Estimation of plasma phosphatase by determination of hydrolysed phenol with antipyrine. J Clin Pathol 1954; 7:322-26.

12. Henry RJ. Clinical chemistry (principles and techniques). N ew Y ork: Harper \& Row 1964.

13. Nelson SD. M olecular mechanisms of the hepatotoxicity caused by acetaminophen. Semin Liver Dis 1990;10:267-78.

14. Pari $L, M$ urugan $P$. Protective role of tetrahydrocurcumin against erythromycin estolate-induced hepatotoxicity. Pharmacol Res 2004;49:481-86.

15. M olander DW, W roblewski F, Ladue JS. Serum glutamic oxalacetic transaminase as an index of hepatocellular integrity. J L ab Clin M ed 1955;46:831-39.

16. Fakurazi S, Hairuszah I, Nanthini U. Moringa oleifera Lam prevents acetaminophen induced liver injury through restoration of glutathione level. Food Chem Toxicol 2008;46:2611-15.

17. Hewitt LA, A yotte P, Plaa GL. M odifications in rat hepatobiliary function following treatment with acetone, 2-butanone, 2hexanone, mirex or chlordecone and subsequently exposed to chloroform. Toxicol A ppl Pharmacol 1986;83:465-73.

\section{ABOUT THE AUTHORS}

\section{Javed Akhtar Ansari (Corresponding Author)}

Department of Pharmacology, MESCO College of Pharmacy M ustaidpura, Hyderabad-500006, A ndhra Pradesh, India, e-mail: javed.ansari47@gmail.com

\section{Abdul Mateen Sayyed}

Department of Pharmacology, MESCO College of Pharmacy M ustaidpura, Hyderabad, A ndhra Pradesh, India

\section{R Manavalan}

Faculty of Pharmacy, A nnamalai University, Chidambaram Cuddalore, Tamil Nadu, India

\section{Balamurgan}

Faculty of Pharmacy, A nnamalai U niversity, Chidambaram Cuddalore, Tamil Nadu, India 